\title{
PENGUKURAN TINGKAT KESIAPAN TEKNOLOGI INFORMASI PADA UNIVERSITAS JENDERAL ACHMAD YANI
}

\author{
Tacbir Hendro Pudjiantoro $^{1)}$, Irma Santikarama ${ }^{2}$, dan Herdy Ashaury ${ }^{3)}$ \\ 1,2,3 Jurusan Informatika, Fakultas Sains dan Informatika \\ Universitas Jenderal Achmad Yani \\ ${ }_{1,2,3} \mathrm{Jl}$. Terusan Sudirman, Cimahi \\ E-mail: tacbir.hendro@lecture.unjani.ac.id ${ }^{1)}$,irma.santikarama@lecture.unjani.ac.id ${ }^{2)}$, ashaury.herdi@gmail.com ${ }^{3)}$
}

\begin{abstract}
ABSTRAK
Universitas Jenderal Achmad Yani (UNJANI) adalah salah satu perguruan tinggi yang terletak di kota Bandung. UNJANI sudah mengunakan sistem informasi akademik berbasis komputer secara terpusat. Sistem informasi yang digunakan tersebut sudah disosialisasikan kepada para penggunanya, hal ini dilakukan oleh UNJANI karena dirasakan sudah waktunya semua sistem yang ada dirubah menggunakan bantuan teknologi informasi. Namun demikian, belum semua sumber daya yang ada di UNJANI mempunyai pengetahuan dan kemampuan yang sama dalam menggunakan sistem informasi berbasis teknologi informasi. Pengukuran pengetahuan dan kemampuan teknologi informasi atau biasa dikatakan tingkat kesiapan yang dimiliki oleh sumberdaya yang ada di UNJANI, dapat dilakukan dengan menggunakan framework STOPE (Strategy, Technology, Organization, People, dan Environtment), yang akan menunjukan tingkat kesiapaan UNJANI dari sisi-sisi strategi teknologi informasi, teknologi yang digunakan, organisasi, sumber daya manusia, dan lingkungan bisnis pada UNJANI. Hasil dari penelitian dapat digunakan untuk pemetaan kemampuan sumberdaya yang ada di UNJANI, dengan pemetaan ini dapat di identifikasi masing-masing unit yang memerlukan pengetahuan dan kecakapan tambahan atau hanya sekedar penyegaran. Kondisi tersebut dapat membantu pihak manajamen UNJANI, untuk meningkatkan pengetahuan dan kemampuan sumberdaya manusia UNJANI dalam teknologi informasi.
\end{abstract}

Kata kunci : Sistem Informasi, Tingkat Kesiapan, Teknologi Informasi, STOPE, Pemetaan

\section{PENDAHULUAN}

Penilaian kesiapan teknologi informasi untuk suatu organisasi semakin penting dilakukan untuk mendukung merencanakan teknologi informasi yang berkelanjutan sehingga dapat sesuai dengan strategi yang telah ditetapkan oleh organisasi (Al-Osaimi, dkk., 2006). Peran teknologi informasi dalam dunia perguruan tinggi khususnya di Universitas Jenderal Achmad Yani sangat penting dalam menunjang proses bisnis, yang salah satunya dengan dikembangkannya sistem informasi yang dalam proses perjalananya ternyata banyak yang tidak termanfaatkan secara maksimal. Diperlukan pengukuran pengetahuan dan kemampuan teknologi informasi atau dapat dikatakan dengan tingkat kesiapan yang dimiliki oleh sumberdaya yang ada di Universitas Jenderal Achmad Yani, dapat dilakukan dengan menggunakan framework atau pendekatan penilaian kesiapan teknologi informasi.

Penilaian kesiapan teknologi informasi atau sering disebut dengan IT Readiness atu e readiness. E-readiness merupakan kemampuan untuk mengejar kesempatan menciptakan suatu nilai dengan difasilitasi oleh penggunaan internet (Septikhtiarif \& Handayaningsih, 2017 ). E-readiness Technology Readiness mengacu pada kecenderungan masyarakat untuk merangkul dan menggunakan teknologi baru untuk mencapai tujuan dalam kehidupan rumah dan di tempat kerja. Konstruk ini dapat dipandang sebagai keseluruhan keadaan pikiran dan penghambat yang secara kolektif menentukan predisposisi seseorang untuk menggunakan teknologi baru (Parasuraman, A., n.d.). Pada umumnya Technology readiness berupa suatu ukuran tingkat kesiapan teknologi yang diartikan sebagai indikator yang menunjukkan seberapa siap atau matang suatu teknologi dapat diterapkan dan diadopsi oleh pengguna/calon pengguna (Parasuraman, A., n.d.). Tingkat Kesiapan Teknologi merupakan suatu sistem pengukuran sistematik yang mendukung penilaian kematangan atau kesiapan dari suatu teknologi tertentu dan perbandingan kematangan atau kesiapan antara jenis teknologi yang berbeda (Parasuraman, A., n.d.).

Metode dan pendekatan penilaian kesiapan berbedabeda sesuai dengan objek yang diteliti dan tujuan yang ingin dicapai. Dengan metode yang tepat dan sesuai dengan objek penelitian, hasil penelitian benar-benar akan menggambarkan kesiapan objek yang diteliti dan membuahkan rekomendasi yag tepat bagi pengembangannya. Namum, idealnya pengukuran kesiapan tersebut diukur secara berkala agar dapat diketahui kelemahan sekaligus solusi untuk pembenahannya (Azab N.A.; Kamel Sherif; Dafoulas Georgios, 2009).

Framework STOPE dipilih karena memiliki domaindomain yang merupakan integrasi dari berbagai factor yang pernah digunakan untuk pengukuran tingkat kesiapan. Framework ini juga telah digunakan dan dikembangkan untuk mengevaluasi berbagai permasalahan teknologi informasi (Hari Susanto, 2004). 
Penelitian sebelumnya dilakukan untuk evaluasi kesiapan perguruan tinggi dalam penerapan sistem informasi akademik di Akademik Pariwisata Yogyakarta (Akparyo) (Setyawan, dkk., 2016). Penelitian ini menggunakan pendekatan framework STOPE (strategy, technology, organization, people, dan environment). Framework STOPE dipilih karena memiliki domaindomain yang sesuai dengan kondisi siap yang diharapkan pemegang kebijakan di Akparyo. Akparyo yang merupakan suatu organisasi di bidang pendidikan tinggi tentunya tidak akan sama dengan organisasi pemerintah, bank, atau perusahaan profit. Sehingga nantinya ada beberapa faktor yang dapat dimodifikasi disesuaikan dengan hal-hal yang mendukung penerapan Sistem Informasi Akademik. Selain itu, pendekatan ini memperkenalkan suatu model analisis matematika untuk melakukan penilaian, yang memungkinkan dilakukan penilaian e-readiness dan pembandingan tingkat pengaruhnya terhadap nilai ereadiness sekaligus pada tiga level yang berbeda (domain, sub-domain, dan sub-subdomain).

Penelitian sebelumnya dilakukan penilaian kesiapan pengalihan PBB pada Pemerintahan Daerah Kabupaten Gunungkidul (Hari Susanto, 2004) yang akan melihat bagaimana tingkat kesiapan Pemerintah Daerah Gunungkidul dalam menerima pengalihan PBB menggunakan pendekatan framework STOPE. Tujuan dari penelitian ini adalah untuk menganalisis tingkat kesiapan pemerintah daerah Kabupaten Gunungkidul dalam proses pengalihan PBB dan mengidentifikasi pengaruh domaindomain pada framework STOPE terhadap implementasi pengalihan $\mathrm{PBB}$.

Penelitian sebelumnya dilakukan e-audit di lingkungan Badan Pemeriksa Keuangan (BPK) RI. E-audit merupakan (Latif, et al., 2012)bagian integral dari Impelementasi egovernment di Iingkungan Badan Pemeriksa Keuangan (BPK) RI. impelementasi e-audit dilakukan secara bertabap berpatokan pada grand design dan peta jalan dimulai dlri 2010 hingga 2014. Keberhasilanya sangat ditentukan oleh sejaub mana kesiapan (readiness) BPK RI, organisasi maupun SDM, terhadap penerapan e-audit tersebut. Penelitian ini bertujuan untuk mengukur kesiapan BPK RI Perwakilan Provinsi Banten terhadap impelementasi eaudit. Peailaian e-audit readiness pada penelitian ini menggunakan Framework STOPE dengan mengevaluasi 5 domain, 14 sub- umain (isu), dan 60 sub-sub-domain (faktor). Basil analisis data menunjukkan bahwa BPK RI Perwakilan Proviosi Banten berada pada peringkat 3 (siap) dari skala 4 untuk mengimplementasikan e-audit. Dari sisi Domain Strategy, Domain Technology, Domain People dan Domain Environment, BPK RI Perwakilan Provinsi Banten berada pada peringkat 3 (siap) pada skala 4 untuk mengimplementasikan e-audit. Namun dari sisi Domain Organization, BPK RI Perwakilan Provinsi Banteo berada pada peringkat 2 (cukup siap) pada skala 4 untuk mengimplementasikan e-audit.

Teknologi informasi di PTS dapat dimanfaatkan pada tiga tingkatan, yaitu dalam memberikan dukungan untuk pelayanan, administrasi, sebagai alat bantu pengajaran dan sarana komunikasi serta pemanfaatan untuk pengambilan keputusan. Teknologi informasi di perguruan tinggi meningkatkan keefektifan dalam hal pelayanan terhadap civitas akademika. Dalam implementasinya, ditemukan berbagai kendala dalam pemanfataan teknologi informasi di perguruan tinggi. Salah satunya adalah ketidaksiapan Sumber daya Manusia (SDM) dalam mengelola teknologi informasi yang akan disediakan. Untuk mengatasi hal ini, perlu diadakan pelatihan bagi SDM agar lebih memahami penggunaan teknologi informasi. Permasalahan kedua yakni soal keuangan, contohnya migrasi data dari dokumen fisik menuju sistem informasi elektronik, tentu saja dibutuhkan biaya yang tidak sedikit. Pengembangan sistem informasi, penyediaan hardware serta software, kebutuhan bandwith dan ruangan untuk penyimpanan server, serta biaya maintenance. Kendala lainnya yang juga mungkin muncul adalah terkait birokrasi kampus.

Universitas Jenderal Achmad Yani sudah menggunakan sistem informasi berbasis teknologi secara terpusat. Pada waktu yang relatif singkat, sistem informasi tersebut dibangun dengan memanfaatkan dana hibah yang didapat Universitas Jenderal Achmad Yani melalui pemerintah. Kondisi tersebut sangat dimanfaatkan dan bermanfaat untuk perkembangan Universitas Jenderal Achmad Yani di periode selanjutnya.

Sistem informasi yang digunakan tersebut sudah disosialisasikan kepada para penggunanya, dan kemudian mereka diberikan pendidikan cara penggunaanya. Hal ini dilakukan oleh Universitas Jenderal Achmad Yani karena dirasakan sudah waktunya semua sistem yang ada dirubah menggunakan bantuan teknologi informasi.

Sistem informasi yang telah dibangun dalam proses perjalananya ternyata banyak yang tidak termanfaatkan secara maksimal. Harapan yang diinginkan tidak sesuai dengan realisasinya. Hal ini secara sepintas dilihat terjadi karena pengetahuan dan kemampuan tentang teknologi informasi para user belum merata. Ketidakmerataan pengetahuan dan kemampuan penggunaan teknologi informasi ini belum diukur sebelumnya, meskipun pada saat sistem informasi yang dibangun itu akan digunakan para user sudah diberikan pelatihan penggunaan sistem informasi.

Namun demikian, belum semua sumber daya yang ada di Universitas Jenderal Achmad Yani mempunyai pengetahuan dan kemampuan yang sama dalam menggunakan sistem informasi berbasis teknologi informasi. Sumberdaya di Universitas Jenderal Achmad Yani mempunyai kemampuan yang beragam terkait teknologi informasi, untuk mengetahui seberapa dalam dan seberapa luas kemampuan yang dimiliki oleh sumberdaya yang ada di Universitas Jenderal Achmad Yani, diperlukan sebuah penelitian yang dapat mengukur pengetahuan dan kemampuan yang dimilikinya.

\section{RUANG LINGKUP}

Pengukuran pengetahuan dan kemampuan teknologi informasi atau tingkat kesiapan teknologi informasi yang dimiliki oleh sumberdaya yang ada di Universitas Jenderal 
Achmad Yani, dapat dilakukan dengan menggunakan framework STOPE (Strategy, Technology, Organization, People, dan Environtment), yang akan menunjukan tingkat kesiapaan Universitas Jenderal Achmad Yani dari sisi-sisi strategi teknologi informasi, teknologi yang digunakan, organisasi, sumber daya manusia, dan lingkungan bisnis pada Universitas Jenderal Achmad Yani.

Pemerataan pengetahuan dan kemampuan menggunakan teknologi informasi menjadi suatu yang sangat diperlukan oleh sumberdaya manusia yang ada di Universitas Jenderal Achmad Yani Universitas Jenderal Achmad Yani agar tujuan dan harapan pembangunan sistem infromasi berbasis teknologi informasi tercapai. Hasil dari penelitian dapat digunakan untuk pemetaan kemampuan sumberdaya yang ada di Universitas Jenderal Achmad Yani, dengan pemetaan ini dapat di identifikasi masing-masing unit yang memerlukan pengehauan dan kecakapan tambahan atau hanya sekedar penyegaran. Kondisi tersebut dapat membantu pihak manajamen Universitas Jenderal Achmad Yani, untuk meningkatkan pengetahuan dan kemampuan sumberdaya manusia Universitas Jenderal Achmad Yani dalam teknologi informasi.

\section{BAHAN DAN METODE}

Pada bagian ini yang akan dibahas adalah materi yang akan di bahas dan metode yang digunkannya.

\subsection{Framework STOPE}

STOPE merupakan kependekan dari Strategy, Technology, Organization, People dan Environment. Bagian-bagian tersebut meliputi dari (Al-Osaimi, dkk., 2006):

1. Strategy : merupakan strategi dari suatu negara dalam memperhatikan perkembangannya di masa depan.

2. Technology : merupakan teknologi dasar yang dimiliki atau digunakan pada industry atau layanan yang menjadi perhatian.

3. Organization : menjelaskan tentang hubungan organisasi dengan industry atau layanan yang menjadi perhatian.

4. People : memaparkan perhatian masyarakat pada tujuan industry atau layanan.

5. Environment : merupakan bentuk lingkungan yang berada disekitar dari industri atau layanan yang akan dituju.

Metode STOPE kerangka kerja yang menyediakan pandangan terstruktur dengan baik terintegrasi dari berbagai faktor yang terlibat (Saleh \& Bakry, 2007) dan memisahkan analisis dari permasalahan pada lima domain tersebut juga dapat menyusun masalah keamanan informasi pada lima domain berbeda (Saleh \& Alfantookh, 2011). Pemisahan analisis tersebut dimaksudkan untuk memberikan perhatian yang lebih baik dalam menganalisis permasalahan yang ada pada sudut pandang strategy, technology, Organization, people, dan Environment.

Framework STOPE mempunyai fitur yang berbeda dengan perangkat pengukuran lainnya, sehingga mempunyai potensi yang baik yang dapat digunakan untuk negara dan atau organisasi pada beberapa bidang yang berbeda (Alfantookh, et al., 2008). Framework STOPE mempunyai sub-domain berdasarkan domain STOPE seperti pada Gambar 1.

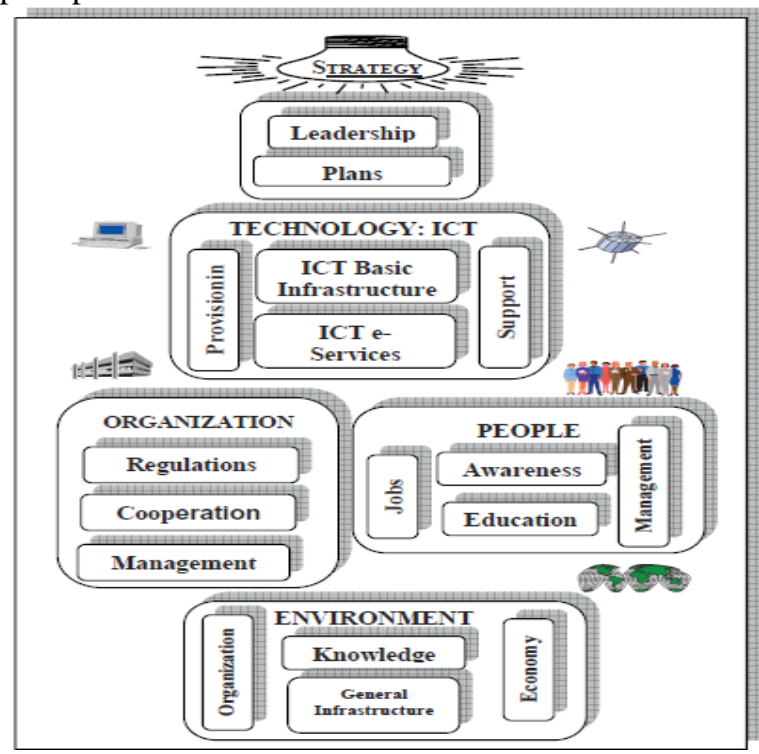

Gambar 1. Framework STOPE

\subsection{Metoda}

Metode yang digunakan dalam penelitian ini terdiri dari beberapa tahapan yang dapat dilihat pada Gambar 2.

Penyesuaian Framework STOPE

Penyusunan Instrumen Pengambilan Data

Survei dan Pengumpulan Data

Analisis dan Pengolahan Data

Perhitungan Tingkat Kesiapan

Dokumentasi dan Publikasi

Gambar 2. Metode Penelitian

Tahapan yang akan dilakukan adalah sebagai berikut :

1. Penyusuaian framework STOPE

Pada tahap ini dilakukan penyesuain terhadap framework STOPE terutama pada bagian domain dan sub domain sehingga dapat sesuai dengan penelitian yang akan dilakkan. Beberapa item diubah karena tidak sesuai dengan kondisi tempat studi kasus yang dilakukan pada Universitas Jenderal Achmad Yani. Setelah dilakukan penyesuaian dengan framework 
STOPE, masing- masing domain pada level factor diberikan indicator kesiapan IT pada Universitas Jenderal Achmad Yani. Masing-masing indicator merupakan gambaran tingkat kesiapan IT pada Universitas Jenderal Achmad Yani.

2. Penyusunan instrument pengambilan data

Pada tahap ini dilakukan penyusunan istrumen pengambilan data dilakukan dengan cara pembuatan kuesioner yang mengacu kepada indicator yang telah disusun pada tahap sebelumnya. Kuesioner ditujukan untuk mendapatkan nilai pembobotan.

3. Survei dan pengumpulan data

Pada tahap ini dilakukan survei dan pengumpulan data yang dilakukan pada Universitas Jenderal Achmad Yani menggunakan instrument yang telah disusun sebelumnya. Survei dilakukan dengan menggunakan perangkat lunak untuk memudahkan dalam pengumpulan data. Adapun tahapan pengambangan perangkat lunak pengolahan kuesioner adalah sebagai berikut:

1) Identifikasi Kebutuhan

2) Analisis

3) Perancangan Perangkat Lunak

4) Implementasi

Dari perangkat lunak pengolahan kuesioner didapat data mentah jawaban dari kuesioner yang diisi oleh responden.

4. Analisis dan pengolahan data

Pada tahap ini dilakukan analisis dan pengolahan data yang dijadikan landasan untuk memberikan penilaian dan pemeringkatan tingkat kesiapan IT pada Universitas Jenderal Achmad Yani. Nilai hasil survei dan pengumpulan data diolah dengan menggunakan persamaan matematis framework STOPE untuk menghasilkan nilai tingkat kesiapan IT pada Universitas Jenderal Achmad Yani.

5. Perhitungan tingkat kesiapan IT

Pada tahap ini dilakukan perhitungan dan tingkat kesiapan IT pada Universitas Jenderal Achmad Yani yang dilakukan dengan mengacu pada pemeringkatan kesiapan skala 4 yang terdapat pada framework STOPE, dengan skala terendah adalah 1 yang menggambarkan kondisi belum siap (not ready), skala 2 yang menggambarkan kondisi cukup siap (almost ready), skala 3 yang menggambarkan kondisi siap (ready), atau skala 4 yang menggambarkan kondisi sangat siap (complety ready).

\section{PEMBAHASAN}

Dalam bagian ini akan dibahasa menegai beebrapa hal yangberkaiatan dengan bahan dan metoda yang digunakan dalam penelitian ini.

\subsection{Penyesuaian Framework STOPE}

Dilakukan penyesuain terhadap framework STOPE terutama pada bagian domain dan sub domain sehingga dapat sesuai dengan penelitian yang akan dilaksanakan. Beberapa item diubah karena tidak sesuai dengan kondisi tempat studi kasus yang dilakukan pada Universitas Jenderal Achmad Yani. Setelah dilakukan penyesuaian dengan framework STOPE, masing- masing domain pada level factor diberikan indicator kesiapan IT pada Universitas Jenderal Achmad Yani. Masing-masing indicator merupakan gambaran tingkat kesiapan IT pada Universitas Jenderal Achmad Yani. Adapun item framework STOPE yang dimodifikasi untuk disesuaikan dengan studi kasus dapat dilihat pada Tabel 1.

Tabel 1. Penyesuaian Framework STOPE

\begin{tabular}{|l|l|l|}
\hline No & Domain & $\begin{array}{l}\text { Item Yang DImodifikasi / } \\
\text { Dieliminasi }\end{array}$ \\
\hline 1 & Strategy & $\begin{array}{l}\text { Tidak ada item yang dimodifikasi / } \\
\text { dieliminasi }\end{array}$ \\
\hline 2 & Technology & $\begin{array}{l}\text { Tidak ada item yang dimodifikasi / } \\
\text { dieliminasi }\end{array}$ \\
\hline 3 & Organizational & $\begin{array}{l}\text { Tidak ada item yang dimodifikasi / } \\
\text { dieliminasi }\end{array}$ \\
\hline 4 & People & Factor Media Support dieliminasi \\
\hline 5 & Environment & Factor Trade dieliminasi \\
\hline
\end{tabular}

\subsection{Penyusunan Instrumen Pengambilan Data}

Dilakukan penyusunan istrumen pengambilan data dilakukan dengan cara pembuatan kuesioner yang mengacu kepada indicator yang telah disusun pada tahap sebelumnya. Kuesioner ditujukan untuk mendapatkan nilai pembobotan. Adapun contoh kuesioner pada domain Strategy yang telah dibuat dapat dilihat pada Tabel 2.

\section{Tabel 2. Contoh Kuesioner}

\begin{tabular}{|c|c|c|}
\hline $\begin{array}{l}\text { Sub } \\
\text { Domain }\end{array}$ & Factor & Statement of Quesioner \\
\hline \multicolumn{3}{|c|}{ Domain : Strategy } \\
\hline $\begin{array}{l}\text { ICT } \\
\text { Leadership }\end{array}$ & $\begin{array}{ll}\text { - } & \text { Vision } \\
\text { - } & \text { Government } \\
\text { - } & \text { Support } \\
\text { - } & \text { Commitments } \\
\text { - } & \text { ICT Manangers } \\
& / \\
& \text { Responsibilities }\end{array}$ & 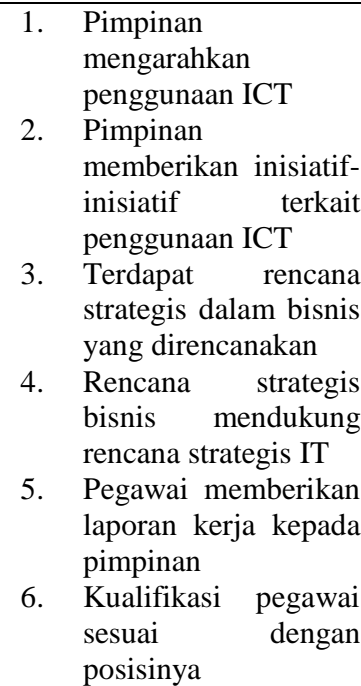 \\
\hline
\end{tabular}




\subsection{Survei dan Pengumpulan Data}

Dilakukan survei dan pengumpulan data yang dilakukan pada Universitas Jenderal Achmad Yani menggunakan instrument yang telah disusun sebelumnya. Survei dilakukan dengan menggunakan perangkat lunak untuk memudahkan dalam pengumpulan data. Adapun hasil pengambangan perangkat lunak pengolahan kuesioner adalah sebagai berikut :

\section{Identifikasi Kebutuhan}

Dalam pengelolaan kuesioner diperlukan suatu system yang dapat mempermudah proses pengumpulan data pada survei yang dilakukan. Perangkat lunak pengolahan kuesioner ini memudahkan responden dalam memberikan data terkait dengan survei yang dilakukan. Proses bisnis dalam perangkat lunak pengolah kuesioner ini dapat dilihat pada Gambar 3.

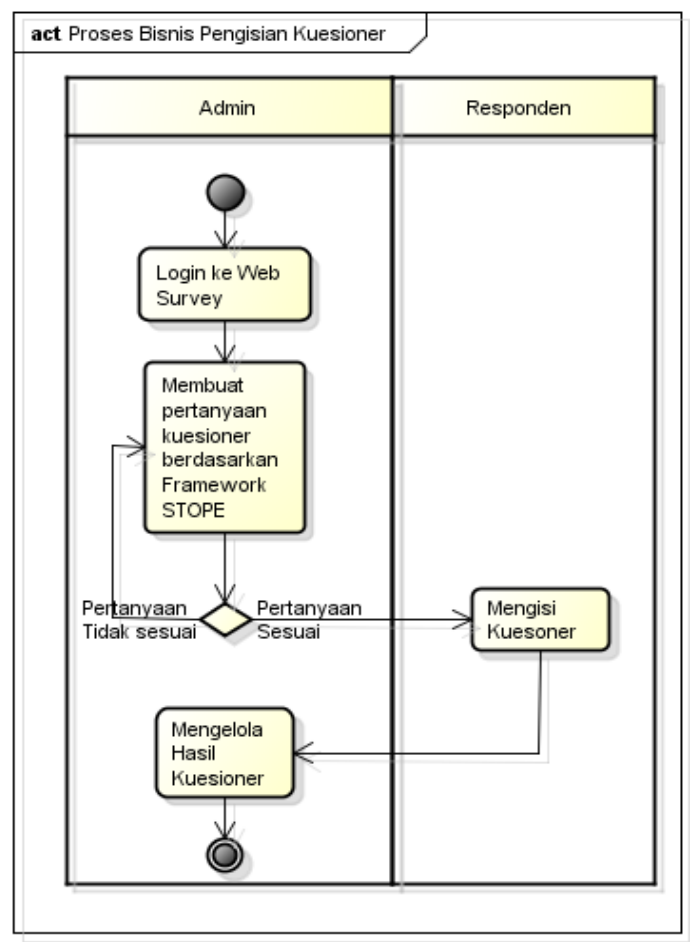

Gambar 3. Proses Bisnis

\section{Analisis}

Analisis terhadap identifikasi kebutuhan pengembangan perangkat lunak pengolahan kuesioner menghasilkan hipotesis awal dilakukan untuk perancangan perangkat lunak. Berdasarkan hasil identifikasi kebutuhan, fungsi yang terdapat pada perangkal lunak pengolahan kuesioner, yaitu :

1) Fungsi login digunakan untuk memberikan hak akses untuk admin. Admin adalah aktor yang memiliki wewenang tertinggi terhadap system. Admin dapat melakukan pengaturan-pengaturan terhadap perangkat lunak pengolah kuesioner berbasis web ini.
2) Fungsi kelola kuesioner digunakan oleh actor admin untuk mengelola kuesioner. Pada fungsi ini, admin dapat melakukan tambah pertanyaan kuesioner, ubah pertanyaan kuesioner, hapus pertanyaan kuesioner, dan lihat pertanyaan kuesioner yang tentunya telah disesuaikan dengan pertanyaan kuesioner berdasarkan framework STOPE.

3) Fungsi kelola hasil kuesioenr digunakna oleh actor admin untuk mengelola hasil kuesioner yang telah dilakukan pengisian kuesioner oleh responden.

4) Fungsi pengisian kuesioner digunakan oleh actor responden untuk melakukan pengisian kuesioner pada perangkat lunak pengolah kuesioner berbasis web.

3. Perancangan Perangkat Lunak

Dalam perangkat lunak pengolah kuesioner berbasis web terdapat 2 user pengguna, yaitu admin dan responden yang terdiri atas berbagai jabatan. Admin dapat melakukan login ke aplikasi web survey, kelola kuesioner, dan menghitung hasil kuesioner. Sedangkan responden dapat melakukan pengisian kuesioner. Apabila dimodelkan dalam use case, dapat dilihat pada Gambar 4.

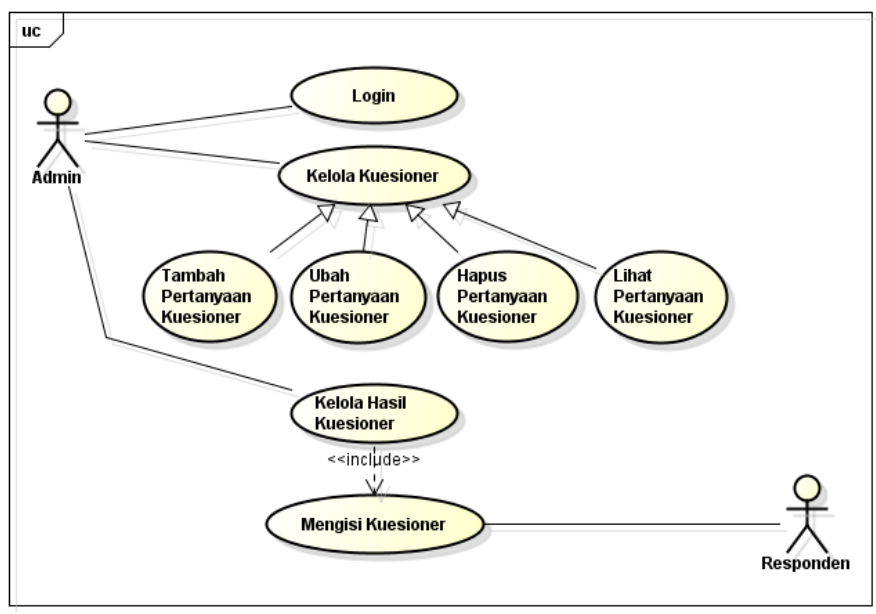

\section{Gambar 4 Use Case Sistem}

\section{Implementasi}

Implementasi perangkat lunak pengolahan kuesioner untuk membantu survei dan pengumpulan data dapat dilihat pada tampilan perangkat lunak pengolahan kuesioner sebagai berikut:

1) Tampilan Admin

Tampilan yang muncul jika user masuk menggunakan otorisasi admin seperti pada gambar 5 . 


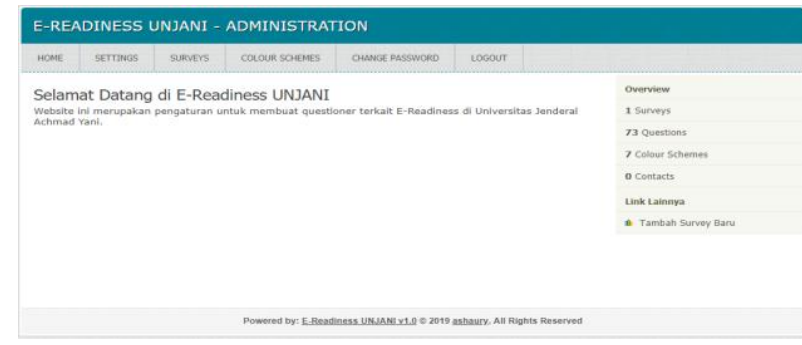

Gambar 5 Tampilan Admin

2) Tampilan Responden

Tampilan yang muncul jika user masuk menggunakan otorisasi responden seperti pada gambar 6 .

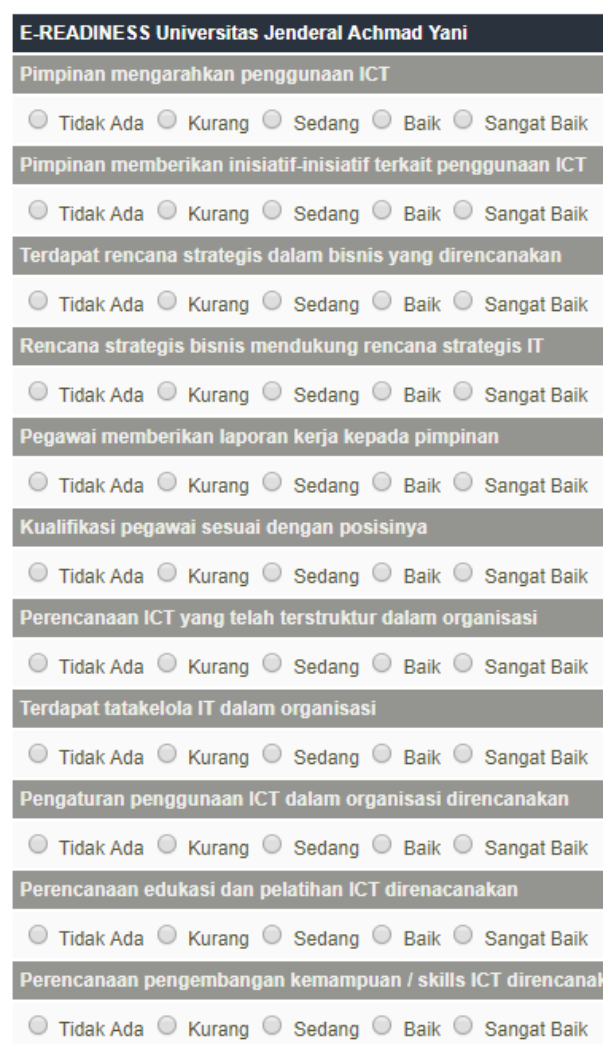

\section{Gambar 6 Tampilan Responden}

Dari perangkat lunak pengolahan kuesioner tersebut telah disebar ke 50 orang responden yang terdiri dari berbagai unit atau bagian dan juga fakultas yang terdiri dari kepala bagian, staff, dan juga dosen yang terdapat di Universitas Jenderal Achmad Yani. Kemudian didapatkan data mentah jawaban dari kuesioner yang telah disebar.

\subsection{Analisis dan Pengolahan Data}

Dilakukan analisis dan pengolahan data yang dijadikan landasan untuk memberikan penilaian dan pemeringkatan tingkat kesiapan IT pada Universitas Jenderal Achmad Yani. Nilai hasil survei dan pengumpulan data diolah dengan menggunakan persamaan matematis framework STOPE untuk menghasilkan nilai tingkat kesiapan IT pada
Universitas Jenderal Achmad Yani. Hasil pengolahan data penilaian pada kelima domain untuk kesiapan IT pada Universitas Jenderal Achmad Yani dari hasil kuesioner dapat dilihat pada tabel 3 .

Tabel 3. Pemeringkatan Kesiapan Pada Domain Utama

\begin{tabular}{|c|l|l|c|c|}
\hline No & \multicolumn{1}{|c|}{ Domain } & $\begin{array}{c}\text { Presentase } \\
(\%)\end{array}$ & Rank & Ket \\
\hline 1 & Strategy & $61,25 \%$ & 3 & Siap \\
\hline 2 & Technology & $62,50 \%$ & 3 & Siap \\
\hline 3 & Organizational & $58,25 \%$ & 3 & Siap \\
\hline 4 & People & $61,50 \%$ & 3 & Siap \\
\hline 5 & Environtment & $63,25 \%$ & 3 & Siap \\
\hline \multicolumn{2}{|c|}{ STOPE } & $\mathbf{6 1 , 3 5 \%}$ & $\mathbf{3}$ & Siap \\
\hline
\end{tabular}

Dari data pada tabel 3 dapat dilihat hasil kesiapan IT pada Universitas Jenderal Achmad Yani untuk domain strategy, technology, people, dan environment sudah memiliki nilai kesiapaan siap, sedangkan untuk subdomain organization memiliki nilai kesiapan cukup siap.

\subsection{Perhitungan Tingkat Kesiapan IT}

Dilakukan perhitungan dan tingkat kesiapan IT pada Universitas Jenderal Achmad Yani yang dilakukan dengan mengacu pada pemeringkatan kesiapan skala 4 yang terdapat pada framework STOPE, dengan skala terendah adalah 1 yang menggambarkan kondisi belum siap (not ready), skala 2 yang menggambarkan kondisi cukup siap (almost ready), skala 3 yang menggambarkan kondisi siap (ready), atau skala 4 yang menggambarkan kondisi sangat siap (complety ready). Berdasarkan analisis dan pengolahan data yang dilakukan pada tahap sebelumnya, didapatkan bahwa tingkat kesiapan IT pada Universitas Jenderal Achmad Yani berada pada tingkat 3 atau Siap untuk mengimplementasikan IT pada Universitas Jenderal Achmad Yani. Grafik tingkat kesiapan IT Universitas Jenderal Achmad Yani dapat dilihat pada gambar 7.

Dari gambar 7 diketahui bahwa domain environment memiliki nilai terbesar yaitu $63,25 \%$, disusul dengan domain technologi dengan nilai $62,50 \%$, lalu domain people dengan nilai $61,50 \%$, dan domain strategy dengan nilai $61,25 \%$. Sedangkan nilai organizational memiliki nilai terendah dengan nilai $58,25 \%$. Hal ini menunjukan bahwa environment Universitas Jenderal Achmad Yani telah mendukung dalam kesiapan IT Universitas Jenderal Achmad Yani, yang didukung oleh tiga domain lainnya, yaitu technology yang telah digunakan, people atau SDM yang telah siap menggunakan perangkat IT, dan strategy dari pimpinan yang telah mendukung penggunaan IT tersebut. Sedangkan domain organizational memiliki nilai yang paling kecil sehingga perlu ditingkatkan factor-faktor dala domain tersebut. Namun, masih harus terus ditingkatkan tingkat kesiapan IT Universitas Jenderal Achmad Yani sampai dengan nilai Sangat Siap untuk menunjang penggunana IT Universitas Jenderal Achmad Yani yang maksimal. 


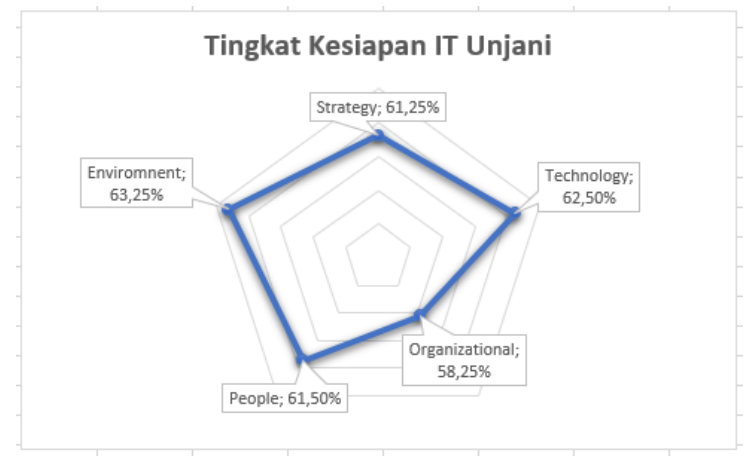

Gambar 7 Grafik Tingkat Kesiapan IT pada Universitas Jenderal Achmad Yani

\section{KESIMPULAN}

Universitas Jenderal Achmad Yani (UNJANI) sudah mengunakan sistem informasi akademik berbasis komputer secara terpusat. Sistem informasi yang digunakan tersebut sudah disosialisasikan kepada para penggunanya, hal ini dilakukan karena dirasakan sudah waktunya semua sistem yang ada dirubah menggunakan bantuan teknologi informasi. Penelitian ini dilakukan untuk meningkatkan kualitas layanan IT di UNJANI secara menyeluruh. Hasil dari penelitian ini adalah pemetaan pengetahuan dan kemampuan tingkat kesiapan IT UNJANI di seluruh bagian berapa pada skala penilaian 3, dengan kata lain masuk dalam kategori "SIAP". Dengan diketahuinya pemetaan pengetahuan dan kemampuan tingkat kesiapan IT UNJANI tersebut dapat dilakukan pihak yang terkait dapat merencanakan dan menyiapkan dana, sarana dan prasarananya di tahun-tahun selanjutnya untuk proses pengembangan dan peningkatannya.

\section{SARAN}

Setalah diketahui pemetaan pengetahuan dan kemampuan tingkat kesiapan IT di UNJANI, agar dapat lebih spesifik mana yang harus di perbaiki secara epat dan khusus, dapat dilakukan peneliatn lanjutan yang berfokus pada salah satu domain saja, sehingga dapat melihat secara lebih detail dan lengkap terhadap suatu domain. Selain itu, untuk pengembangan penelitian selanjutnya dapat dilakukan tentang Audit Sistem Informasi yang ada pada UNJANI, ini dilakukan untuk melihat apakah proses pada sistem informasi yang telah digunakan telah sesuai dengan kebutuhan yang diharapkan. Hasil survey digunakan untuk evaluasi kinerja terhadap pelaksanaan penggunaan IT di Unjani.

\section{DAFTAR PUSTAKA}

Al-Osaimi, K., Alheraish, A., \& Bakry, S. H. 2006. An Integrated STOPE Framework for e-Readiness Assessment. 18th National Computer Conference

Alfantookh, Abdulkader A, Al-Hazmi, Khaled M., Bakry. 2008. Assessment Indicators for Information Technology in Higher Education Institutions: A STOPE Approach, Asian Journal of Information Management, 1-13.

Azab N.A., Kamel Sherif;, Dafoulas Georgios. 2009. A Suggested Framework for Assessing Electrinic Government Readiness id Egypt. Electronic Journal of E-Government, 11-28.

Faozi Septikhtiarif, Sri Handayaningsih. 2017. Pengukuran E-Readiness Menggunakan Framework Stope Pada Proses Pengajuan Cuti Akademik Perguruan Tinggi. Procedng Annual research Seminar, 173-177.

Hari Susanto, A. S. 2004. Pendekatan Framework STOPE untuk Kesiapan Pengalihan PBB pada Pemerintahan Daerah Kabupaten Gunungkidul. Seminar Nasional Teknologi Informasi dan Multimedia, 49-56.

Latif, A., Wahyu, W., \& Surjono. 2012. Penilaian E-Audit Readiness dengan Pendekatan Framework STOPE pada Badan Pemeriksa Keuangan (BPK) RI Perwakilan Provinsi Banten. Jurnal Nasional Teknik Elektro dan Teknologi Informasi, 01.

Parasuraman, A. (n.d.). Technology Rediness Index (TRI) a multiple-item scale to measure rediness to embrace new technology. Journal of Service Research, 2, 307320.

Saleh, Mohamed S, Alfantookh, Abdulkader, 2011. A new comprehensive framework for enterprise information security risk management, Jurnal Applied Cyomputing and Informatics, King Saud University, 107-118.

Saleh, Mohamed S, Bakry, Abdullah Alrabiah and Saad Haj, 2007, A STOPE model for the investigation of compliance with ISO 17799-2005, Information Management \&Computer Security, 183-294

Setyawan, W. M., Winarno, W. W., \& Luthfi, E. T. 2016. Evaluasi Kesiapan Perguruan Tinggi dalam Penerapan Sistem Informasi Akademik. Jurnal INFORMA Politeknik Indonusa Surakarta, 52-60.

\section{UCAPAN TERIMAKASIH}

Terima kasih kami ucapkan kepada LPPM Universitas Jenderal Achmad Yani yang telah memberikan dana penelitian internal dalam penelitian ini sehingga penelitian ini dapat berjalan dengan baik, lancar, dan sukses. Tidak

lupa kami ucapkan terimakasih untuk rekan Tenaga

Kependidikan dan Dosen yang kami mintai pendapatnya untuk mengisi survey yang kami lakukan. 